\title{
HABITAT CONDITIONS OF DESMANA MOSCHATA (TALPIDAE, EULIPOTYPHLA, MAMMALIA) IN THE BUFFER ZONE OF THE PRISURSKIY STATE NATURE RESERVE (RUSSIA)
}

\author{
Marina V. Rutovskaya ${ }^{1, *}$, Alexander N. Aleksandrov², \\ Valentina N. Podshivalina ${ }^{2,4}$, Alena S. Soboleva ${ }^{1,3}$, Oleg V. Glushenkover, \\ ${ }^{1} A . N$. Severtsov Institute of Ecology and Evolution of RAS, Russia \\ ${ }^{2}$ Prisurskiy State Nature Reserve, Russia \\ ${ }^{3}$ Russian State Agrarian University - Moscow Timiryazev Agricultural Academy, Russia \\ ${ }^{4}$ Chuvash State University, Russia \\ ${ }^{5}$ Chavash Varmane National Park, Russia \\ *e-mail:desmana@yandex.ru
}

Received: 29.06.2019. Revised: 20.11.2019. Accepted: 22.02.2020.

\begin{abstract}
The study of bathymetry, macrozoobenthos abundance and the Russian desman population has been performed in the water bodies located in the Prisurskiy State Nature Reserve buffer zone (River Sura lower reaches floodplain). Twenty-one water bodies were examined in total. In six lakes, Desmana moschata (Russian desman) was absent. In nine lakes, the settlement density was less than 5 burrows per $1 \mathrm{~km}$ coastline. And in six lakes, the settlement density was high (i.e. more than 5 burrows per $1 \mathrm{~km}$ ). The studied parameters of the lake basin included the depth of the lake, the water acidity $(\mathrm{pH})$, dissolved oxygen concentration, the type of the plant cover of the shoreline (forest, shrub, steppe), and anthropogenic load. The taxonomical analysis and individual weighing of the animals in the macrozoobenthos samples were performed. All the parameters were then included to an analysis of the Russian desman density. The factors affecting the density of the Russian desman burrows were revealed. The water bodies having more than five burrows per $1 \mathrm{~km}$ along the shoreline are characterised by a higher abundance of macrozoobenthos and especially by the highest mollusk biomass. In turn, the abundance of mollusks, the main food, depends on the dissolved oxygen concentration in the water, trophic state of the lake, and the bottom slope. The highest density of the Russian desman was registered in the lakes characterised by a high biomass of the gastropods Lymnaea stagnalis and Viviparus (Contectiana) contecta. It was noticed that the Russian desman preferred to inhabit wide-course water bodies characterised by a high density of trees or bush along the shoreline. Therefore, the factors mentioned above may appear as the indirect characteristics of the water body with optimal habitat conditions for the Russian desman. Other water body characteristics, such as depth, may define the temporary optimum conditions for the Russian desman inhabiting. The combination of different conditions in a certain area allows the Russian desman to choose suitable water bodies, depending on the annual climatic conditions. There is a combination of a steppe (meadow) and forest areas in the River Sura lower reaches floodplain. Thus, this floodplain may be named as the most suitable for the Russian desman inhabitance.
\end{abstract}

Key words: floodplain, fodder base, habitat preference, macrozoobenthos, Russian desman, River Sura lower reaches

\section{Introduction}

The Russian desman (Desmana moschata Linnaeus, 1758) is a semi-aquatic mammal. It belongs to the order Soricomorpha. It inhabits central European Russia. Most of the population is distributed along the River Volga tributaries. Once a numerous and common commercial species (Borodin, 1963), it is currently in a critical condition. The dynamics of the Russian desman population exhibits a constant decrease. In 1970, the species stock was estimated at 70900 individuals. But only 15 years later (1985), the number decreased by $42 \%$ to 40800 . (Khakhin \& Ivanov, 1990). After the next 15 years (2001), the Russian desman population was estimated as 28000 individuals (Khakhin, 2009). And in 2017, only 8000 animals were left (Rutovskaya et al., 2017). Demolishing of the suitable habitats, poaching and recently climate warming are the main factors of the population decrease (Onufrenya \& Onufrenya, 2016).

The Russian desman inhabits floodplain water bodies only. It totally avoids fast flow. With the onset of the spring flood, animals have to leave the flooded areas. The life of the Desmana moschata is favoured by a small annual amplitude of the water level in the floodplain water bodies, smooth spring floods and an increased moisture content of the floodplain soils during the rest of the year. And, vice versa, violent high floods in spring and insufficient water supply in the rest of the year may have a negative effect (Borodin, 1963). The forest plays an important role, largely regulating the hydrological regime of the water bodies and inhibiting the water flow during the spring flood, forming backwater with a quiet course, where the Desmana moschata prefers to live. In addition, the forest and isolated trees serve as the shelter places 
for the animals during the flood. They moderate the strength of the wind, reduce the moisture loss by soil, and their root system protects the desman burrows from destruction (Borodin, 1963). Also deforestation in the floodplain and land reclamation leading to the shallowing are among the factors limiting the Russian desman abundance (Barabash-Nikiforov, 1968; Onufrenya, 1986).

Floodplain water bodies inhabited by Desmana moschata may be divided into three size groups. The first group includes small water bodies freezing in winter and drying out in summer. Such water bodies are seasonal for the Russian desman. They are not populated every year and play a role for the food search. The second group comprises large (several kilometres long), deep oligotrophic water bodies. As a rule, the Russian desman inhabits these only during particular dry years, populating some backwaters. Finally, the third group is represented by the medium-sized water bodies that do not freeze from surface to bottom in winter and warm well in summer. The Russian desman settles there most readily, even in adverse years (Nazyrova, 2000).

The optimal biotope model for the Russian desman is as follows: it is a permanently closed water body, rather old, occupying a riverbed or central position on the floodplain and forming a single system with the river. Its depth is about $2-3 \mathrm{~m}$ to $5 \mathrm{~m}$ by the time of freezing (i.e. water body does not freeze in winter); one of the coasts must be up to 2-3 $\mathrm{m}$ high; its slope steepness reaches $30^{\circ}-50^{\circ}$. However, the coastal bank has a slightly inclined character (about $15^{\circ}$ ). The shores are composed of clay deposits or sand/sandy loam light soils; the bottom sediments are well pronounced. The regime of the water body in the summer - winter period is stagnant or with a low flow. During the flood period, the flow rate is rather high. A water mirror is covered by $40-60 \%$ with a higher aquatic vegetation (hydrophytes and hydatophytes). Isolated shrubs or willow (Salix spp.) clumps are usually noted along the water edge. The forest cover of this biotope, as well as its neighbouring ones, is high and amounts up to $80-90 \%$. Therefore, Russian desman's burrows turn out to be wellfortified by the roots of trees or shrubs. The aquatic fauna is represented by several species of leeches, insects and their larvae, mollusks, and other invertebrates. The biomass of benthic organisms exceeds $700-800 \mathrm{~g} / \mathrm{m}^{2}$. The degree of anthropogenic pressure on the water body, its coast, and on the surrounding phytocenosis is not significant. Fishing is allowed only with fishing rods. Cattle do not graze along the shores of such water bodies (Nazyrova, 2000).
The degree of overgrowing of the water body can also be important. As the fruits of Nymphaea alba L., shoots of Glyceria spp., arrowhead tubers of Sagittaria sagittifolia L., rhizome of Typha spp. are food for Desmana moschata. The aquatic vegetation also serves as a place for the development of invertebrates that make up the Russian desman's food. On the other hand, a strong overgrowing of coasts with Phragmites australis (Cav.) Trin. ex Steud., Typha spp., and Stratiotes aloides L. creates obstacles for D. moschata's moving and leads to a shallowing and waterlogging of the water bodies. When the overgrowing is severe, the plant biomass increases, which, when decomposed, replenishes water with mineral salts. But this process takes up a lot of oxygen. Finally, the vegetation decomposition in absence of oxygen leads to the release of hydrogen sulfide. Therefore, the Russian desman prefers the ponds with narrow coastal stripes of surface vegetation, formed mostly by sedges, and the water surface free from the aquatic vegetation must exceed $50 \%$ of the water mirror (Samarin, 1975).

The Russian desman inhabits floodplain lakes very unevenly. In the same areas in some water bodies a relatively higher abundance of animals is observed over a number of years than in the others. The assumption that this is caused by different fodder bases in the lakes, which may be assessed by the food biomass and abundance in different seasons, is not confirmed, although relatively large (more than 0.03 $\mathrm{m}^{2}$ ) pond-type lakes are the best feeding areas. They are characterised by $40-50 \%$ overgrowing by aquatic vegetation, dominating depths of 1-2 $\mathrm{m}$ (at low water) and non-bogged shores. The diversity and «mosaicity» of plant associations also positively affects the formation of conditions for the development of the fodder base for the Russian desman (Khakhin \& Ivanov, 1990). When analysing the fodder base in the forest floodplain water bodies of the River Klyazma, it was shown that the water bodies are maximally populated by the Russian desman in sites, where the shallow water area is larger (where the Russian desman mainly feeds) and where the invertebrate fauna develops better in warm water (Ivanov, 1981).

The temperature regime in the water and soil, where the Russian desman's burrows are located, is another important trait of the water body affecting its choice by the Desmana moschata. The temperature regime of the desman habitat is the most important factor determining the survival of this species, since the conditions of animals leading a semi-aquatic life impose a number of severe restrictions. First of all, this is 
the thermoregulation system of the animal (Sukhov \& Onufrenya, 1990).

The climate warming is one of the main factors limiting the Desmana moschata abundance nowadays, since it affects the hydrological regime of the river. The floods become low or are absent in general; water bodies become shallow, which, in turn, leads to overheating in summer. All these processes have a negative impact on the Russian desman reproduction (Rutovskaya et al., 2013). The combination of water bodies with steppe and forest shoreline in floodplain allows the Russian desman to choose between the water bodies with different water temperature conditions within a relatively small area (Eskova et al., 2018). This increases the Russian desman population success. The River Sura floodplain, belonging to the buffer zone of the Prisurskiy State Nature Reserve, is a complex of steppe and forest landscapes that promotes the Russian desman population restoration in the lower reaches of this river (Rutovskaya et al., 2018).

The assessment of habitats in the River Sura floodplain demonstrated that the habitats are used by the Russian desman only partially (Glushenkov et al., 2018), i.e. the Russian desman inhabits only the most suitable water bodies there. Therefore, it makes it possible to define the habitat optimum for the Russian desman under changing climate warming conditions.

The study aims to search for the optimal environment conditions for the Russian desman's habitat. This will allow us to identify the most important factors affecting the Russian desman's survival under current conditions and may be useful in developing a strategy for the conservation of this threatened endemic species.

\section{Material and Methods}

The survey on water body morphometry and macrozoobenthos sampling were performed in the period of 01 July - 15 September 2018. The study of the Russian desman population was conducted during 20-31 October 2018. Twenty-one water bodies have been studied in the River Sura lower reaches floodplain, located in the western part of the buffer zone of the Prisurskiy State Nature Reserve.

There are about 300 lakes with a water-surface area more than $100 \mathrm{~m}^{2}$ in the Protected Area. The water bodies studied were chosen in regard to easy access by the researchers, shoreline parameters (swampy shores are not suitable for colonisation by the Russian desman), and working conditions (water bodies with mud flat, steep banks, overgrown shrubs and littered with tree trunks, are difficult to survey).
The studied water bodies were grouped in regard to the Russian desman population density: A - water bodies, where the burrows were not found, i.e. the population density is assumed to be zero (lakes Kozulishnoe, Vilky, Verkhnee, Bolshoy Buymas, Bashkirskoe (Russian desman inhabited it in 2016), and Bazarskoe (one old burrow was found)); B - water bodies with a low burrow density, i.e. $0<$ group $\mathrm{B}<5$ burrows per $1 \mathrm{~km}$ shoreline (lakes Maloe Shchuchye, Bolshoe Shchuchye, Kirkeri, Zaton, Skobtsy, Chirmen Glukhoe, Lapshevoe, and Staritsa); $\mathrm{C}$ - water bodies with a high burrow density, i.e. group $\mathrm{C} \geq 5$ burrows per $1 \mathrm{~km}$ shoreline (lakes Krivoe, Chebak, Staraya Staritsa, Lisa, Kuryukaly, and Chaga).

A bathymetric survey of the lake basins was carried out using an echo sounder or a rope lot to control extreme data obtained by the echo sounder. The co-ordinates of measuring sites of depth were obtained using Garmin Etrex 20. The water table level was defined using a topographical plan (scale $1: 25000$ ). In order to develop the lake bathymetry scheme and for morphometry index calculations, the co-ordinates of measuring sites were plotted on the map with a satellite image (spatial resolution not more than $10 \mathrm{~m} /$ pixel). The area of the lakes and the sites limited by certain isobaths and the isobaths length were calculated using Mapinfo 15.0. The lake basin volume was calculated by a formula of a truncated cone (Bogoslovsky, 1960). The maximum basin depth was measured during the bathymetry survey. The mean depth was calculated as a quotient from water volume and the area of the lake cone (Bogoslovsky, 1960). The index of the lake basin capacity (basin form index) is the relation of the mean depth to the maximal depth (Kitaev, 2007). The relative depth is the relation of the maximum depth to the effective diameter of the lake surface expressed as a percentage (Wetzel, 2001). The shoreline development is the shoreline length relation to a circumference of a circle equal to a lake surface area (Wetzel, 2001).

The surface water temperature and the water transparency in the pelagic zone were measured due to standard methods (Abakumov et al., 1992). The water acidity $(\mathrm{pH})$ and dissolved oxygen concentration were measured using HANNA HI 83141 and HANNA HI 9147-04 probes respectively. The water body trophic state was assessed by Trophic State Index (TSI) (Carlson, 1977) using the data on the water transparency.

The Ivanov (1949) classification has been applied to determine the water body type in regard to 
the lake area and mean depth. The names of the water bodies are given according to the recommended toponymy (Aleksandrov, 2015). Coastal afforestation was calculated using a point system. The length of the shore of a water body covered by forest, shrubs, or without woody vegetation was measured using the Yandex map on 15 February 2019. Then afforestation was evaluated in points: 1 - more than $50 \%$ of the coast does not have a woody vegetation; 2 - more than $50 \%$ of the coast is overgrown with shrubs or trees, the rest of the coast does not have a woody vegetation; 3 - more than $75 \%$ of the coast is overgrown with shrubs, $4-25-50 \%$ of the coast is overgrown with forests, the rest with shrubs, 5 - forest and shrubs overgrow the coasts approximately equally; 6 - more than $75 \%$ of the coast is overgrown with forest.

The human activity in a floodplain is considered as one of the main reasons influencing the Russian desman number and disappearance (Khakhin \& Ivanov, 1990). This parameter was also estimated on a mark system: 1 (critical) - drainage reclamation is carried out in a floodplain, plowing more than $50 \%$ of the floodplain meadows; clear cutting of the floodplain forests; regulated fishing with fixed nets; presence of camp sites, holiday houses, camps; cattle grazing with density of more than 200 animals per $10 \mathrm{~km}^{2}$ of pastures; pig grazing by pigs. 3 (reducing) - plowing of $20-50 \%$ of floodplain meadows; sanitary deforestation in the floodplain forests; intensive fishing for semi-aquatic animals; regulated fishing with fixed nets; cattle grazing with density of more than 200 animals per $10 \mathrm{~km}^{2}$ of pastures. 7 (restraining) - plowing less than $20 \%$ of floodplain meadows; sports hunting for waterfowl; net fishing; isolated cases of fishing with fixed nets; cattle grazing with density of $90-150$ animals per $10 \mathrm{~km}^{2}$ of pastures; intensive fishing for semi-aquatic animals. 10 (not influencing) - mowing not affecting the coast of water bodies; sports hunting and fishing in designated areas; moderate grazing of cattle with density of no more than 90 animals per $10 \mathrm{~km}^{2}$ of pastures. Necessary parameters for evaluation test of water bodies were received during hydrological studies.

The macrozoobenthos samples were collected in the littoral zone of 25 lakes using a hydrobiology scraper, at a depth about $1 \mathrm{~m}$, which is the preferable feeding zone for the Russian desman in summer (Borodin, 1963). The sample collection and processing were performed according to standard methods (Mitropolsky \& Morduhay-Boltovskoy, 1975). The taxonomical analysis and measuring the individual dry weight of the organisms have been carried out.
The macrozoobenthos has been characterised by several parameters as a forage object: biomass and abundance per acre of the bottom, the biomass share of the major (leeches, larvae of insects, mollusks), minor (imago of insects, oligochaetes) and accidentally eaten (crustaceans, ticks, spiders) food items (Borodin, 1963; Khakhin \& Ivanov, 1990), as well as the feeding value of a prey (Borodin, 1963). The frequency of occurrence was used to determine the degree of taxon dominance (Pesenko, 1982).

The survey for assessing the Russian desman population in the studied water bodies was performed during 21-26 October 2018, according to Borodin (1963). The Russian desman burrows were searched along the shoreline from the water. The Russian desman burrow has an outlet under the water and it continues with a well-defined trench. The inhabited (visited) burrow is distinguished by a hard bottom of trench and absence of silt. Bitten mollusks («fodder tables») are the additional evidence of the Russian desman's presence. The found hole was marked with GPS co-ordinates. In order to obtain a more accurate estimate of the abundance, at least $50 \%$ of the coastline of the water bodies that were considered to be accounted was examined. In order to estimate the burrow density (BD) the number of the registered inhabited burrows has been divided by the number of kilometres of the surveyed shoreline. The total Russian desman population number on the surveyed area was assessed by multiplication of the burrow density to 1.1, which was the average coefficient for October (time of survey) calculated by Borodin (1963), and then to the total shoreline length of the lakes suitable for the Russian desman inhabiting. In 2018, the total stock of the Russian desman in the Prisurskiy State Nature Reserve buffer zone was approximately 390 individuals (Glushenkov et al., 2018).

The local habitat features (measured indicators and the calculated integrated coefficients reflecting the morphometric features of water bodies, as well as hydrophysical characteristics) and feeding conditions in littoral (quantitative parameters of the development of the macrozoobenthos community and its composition) were considered as the main factors determining the distribution of the Russian desman in the floodplain.

The Spearman rank order correlation, dispersion analysis of ANOVA (STATISTICA 13.0) and canonical correlation analysis (CCA, CANOCO for Windows 4.5) were applied to assess the potential impact of abiotic and biotic environmental parameters on the Russian desman occurrence in the water bodies of the River Sura lower reaches floodplain. 


\section{Results}

In the River Sura lower reaches floodplain, the Russian desman inhabits both small and large water bodies. The area of a water mirror varies from $15000 \mathrm{~m}^{2}$ to over $250000 \mathrm{~m}^{2}$ (Table 1). A trend of inhabiting larger water bodies is noted (Table 1), but it is statistically insignificant (ANOVA). Meanwhile, a higher burrow density in wider water bodies is reliable (CCA, $F=6.09 ; p=0.02 ; n=21$, variance explained by the variable is 0.20 ). In inhabited water bodies, the mean depth exceeds $1.5 \mathrm{~m}$, the maximum depth is $4 \mathrm{~m}$. However, it does not differ from the same indicators of water bodies in which the Russian desman is absent. The bottom slope in the water bodies inhabited by the Russian desman is steeper on average than that in non-inhabited ones (Table 1). However, these differences are statistically insignificant.

The forest density along the shoreline is another important factor, which was estimated in points. There is a statistically weak trend, when the Russian desman prefers the water bodies with a high degree of shore overgrowth with forest or shrubs (Table 1, Fig. 1).
As for the anthropogenic load, the inverse trend is observed: the most inhabited water bodies are under less pressure (Table 1), and it is also statistically weak.

In general, the fodder base explains the Russian desman population density in the River Sura lower reaches (Table 2). In addition, the mollusk biomass is the main macrozoobenthos characteristic, which is responsible for $29 \%$ of the Russian desman population density variability difference (insect larvae, for 16\%).

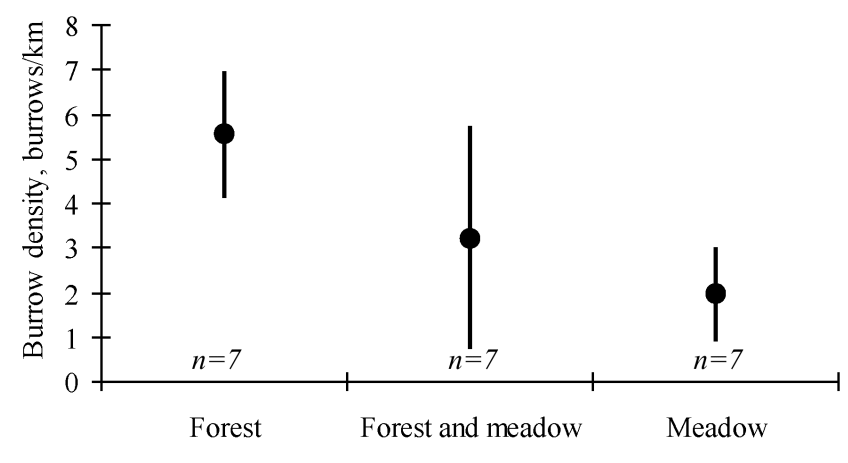

Shoreline

Fig. 1. The Russian desman burrow density (mean $\pm \mathrm{SE}$ ) in the lakes with forest, meadow, and mixed (forest + meadow) shoreline; $n$ - number of surveyed lakes.

Table 1. The lake morphometry, anthropogenic load and the shoreline characteristics of the surveyed water bodies

\begin{tabular}{|c|c|c|c|c|c|c|c|}
\hline $\begin{array}{l}\text { Burrow density, } \\
\text { burrows/km }\end{array}$ & Lake & Area, $10^{3} \mathrm{~m}^{2 *}$ & Mean width, $m$ & $\begin{array}{c}\text { Maximum } \\
\text { depth, } m\end{array}$ & Bottom slope, ${ }^{\circ}$ & $\begin{array}{c}\text { Anthropogenic } \\
\text { load, degree }\end{array}$ & $\begin{array}{c}\text { Forest density along a } \\
\text { shoreline, degree }\end{array}$ \\
\hline \multirow{6}{*}{$\begin{array}{c}\mathrm{A} \\
\mathrm{BD}=0\end{array}$} & Kozulishnoe & 12.9 & 32.8 & 1.8 & 4 & 7 & 3 \\
\hline & Vilky & 16.5 & 25.4 & 2.7 & 16 & 3 & 3 \\
\hline & Verkhnee & 27.5 & 43.0 & 5.0 & 13 & 7 & 3 \\
\hline & Bolshoy Buymas & 81.3 & 69.8 & 4.7 & 20 & 5 & 1 \\
\hline & Bashkirskoe & 100.7 & 93.6 & 3.0 & 8 & 3 & 3 \\
\hline & Bazarskoe & 131.9 & 75.3 & 4.1 & 18 & 3 & 6 \\
\hline $\begin{array}{c}\text { Mean } \\
\text { (group A) }\end{array}$ & $n=6$ & $61.8 \pm 20.3$ & $56.7 \pm 11.0$ & $3.6 \pm 0.5$ & $13 \pm 3$ & 4.6 & 3.2 \\
\hline \multirow{9}{*}{$\begin{array}{c}\mathrm{B} \\
0<\mathrm{BD}<5\end{array}$} & \begin{tabular}{|l|} 
Maloe \\
Shchuchye
\end{tabular} & 27.0 & 40.0 & 3.8 & 14 & 3 & 2 \\
\hline & \begin{tabular}{|l|} 
Bolshoe \\
Shchuchye
\end{tabular} & 61.3 & 46.4 & 11.4 & 65 & 3 & 6 \\
\hline & Kirkeri & 31.8 & 61.9 & 3.3 & 17 & 7 & 4 \\
\hline & Zaton & 35.4 & 47.8 & 2.1 & 8 & 1 & 4 \\
\hline & Skobtsy & 40.4 & 79.9 & 3.9 & 13 & 7 & 3 \\
\hline & Glukhoe & 87.5 & 118.0 & 3.7 & 9 & 7 & 5 \\
\hline & Lapshevoe & 89.2 & 93.1 & 3.8 & 11 & 7 & 6 \\
\hline & Staritsa & 392.2 & 106.3 & 6.0 & 18 & 3 & 2 \\
\hline & Chirmen & 50.6 & 42.6 & 8.1 & 65 & 3 & 6 \\
\hline $\begin{array}{c}\text { Mean } \\
\text { (group B) }\end{array}$ & $n=9$ & $90.6 \pm 38.5$ & $70.7 \pm 9.9$ & $5.1 \pm 1.0$ & $24 \pm 7$ & 4.6 & 4.2 \\
\hline \multirow{6}{*}{$\begin{array}{c}\mathrm{C} \\
\mathrm{BD}>0.5\end{array}$} & Krivoe & 15.7 & 33.9 & 5.7 & 39 & 3 & 3 \\
\hline & Chebak & 94.3 & 70.5 & 5.1 & 30 & 3 & 5 \\
\hline & Lisa & 100.4 & 68.5 & 1.9 & 2 & 7 & 3 \\
\hline & Staraya Staritsa & 123.8 & 67.9 & 2.8 & 9 & 3 & 6 \\
\hline & Kuryukaly & 156.1 & 83.2 & 4.0 & 14 & 3 & 6 \\
\hline & Chaga & 257.0 & 130.5 & 8.4 & 33 & 3 & 6 \\
\hline $\begin{array}{c}\text { Mean } \\
\text { (group C) }\end{array}$ & $n=6$ & $124.6 \pm 32.6$ & $75.7 \pm 12.8$ & $4.7 \pm 0.9$ & $21 \pm 6$ & 3.7 & 4.8 \\
\hline ANOVA & $\begin{array}{l}\text { Comparison of } \\
\text { the three groups }\end{array}$ & $\begin{array}{c}F_{2,18}=0.71 \\
p=0.506\end{array}$ & $\begin{array}{c}F_{2,18}=0.69 \\
p=0.514\end{array}$ & $\begin{array}{l}F_{2,18}=0.79 \\
p=0.471\end{array}$ & $\begin{array}{c}F_{2,18}=0.73 \\
p=0.494\end{array}$ & $\begin{array}{c}F_{2,18}=0.43 \\
p=0.656\end{array}$ & $\begin{array}{c}F_{2,18}=1.71 \\
p=0.209\end{array}$ \\
\hline
\end{tabular}


Table 2. The factors affecting the Russian desman density in the River Sura lower reaches floodplain

\begin{tabular}{|l|c|c|c|c|}
\hline Parameters & $R$ & $F$ & $R^{2}, \%$ & $p$ \\
\hline Macrozoobenthos biomass & 0.53 & 8.7 & 28 & 0.01 \\
Main forage biomass & 0.55 & 9.5 & 30 & 0.01 \\
Gastropod biomass & 0.54 & 9.2 & 29 & 0.01 \\
Insect larvae biomass & 0.42 & 4.8 & 16 & 0.04 \\
\hline
\end{tabular}

Note: $R$ - coefficient of partial correlation, $F-F$-test, $R^{2}-$ coefficient of determination, $p$ - significance value; $n=10$.

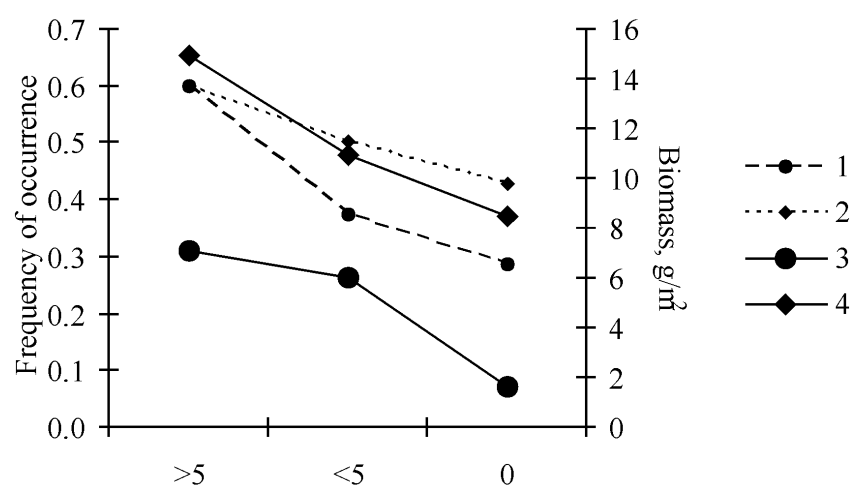

Burrows' density, burrows/km

Fig. 2. The frequency of occurrence (dashed line) and biomass of the gastropods Viviparus (Contectiana) contecta (1, 3 ) and Lymnaea stagnalis $(2,4)$ in the water bodies with different burrow density of the Russian desman.

The occurrence and biomass of the gastropods Lymnaea stagnalis (Linnaeus, 1758) and Viviparus (Contectiana) contecta (Millet, 1813) are higher in water bodies with the highest Russian desman density (Fig. 2). The biomass of some other gastropod species, Lymnaea ovata (Draparnaud, 1805), Lymnaea palustris palustris (Müller, 1774), Viviparus viviparus (Linnaeus, 1758), Bithynia tentaculata (Linnaeus, 1758), Anisus vortex (Linnaeus, 1758), is higher $(56,10,4,2.5$, and 14 times, respectively) in the water bodies with relatively high desman density ( $>5$ desman burrows per 1 $\mathrm{km}$ shoreline, group C) in comparison with the lakes where the Russian desman is absent. And the gastropod occurrence is nearly equal in all water bodies.

In the studied water bodies, the factors affecting the bivalve biomass were revealed using regression analysis (Table 3). Heavy slope gradient, dissolved oxygen concentration and water body trophicity explain 94\% mollusk biomass variability in the floodplain water bodies. The model for mollusk biomass provisional forecast in the floodplain water bodies may be assumed using the data presented in Table 3 (intercept is -87.9).
Table 3. The factors affecting the mollusk biomass in the water bodies of the Sura River lower reaches floodplain

\begin{tabular}{|l|c|c|c|}
\hline \multicolumn{1}{|c|}{ Parameter } & $R^{*}$ & $p$ & $F$ \\
\hline Slope gradient & 0.36 & 0.04 & \\
Dissolved oxygen concentration, \% & 0.91 & 0.01 & 13.7 \\
Trophic state index & 0.46 & 0.02 & \\
\hline
\end{tabular}

Note: $R$ - coefficient of partial correlation, $F-F$-test, $p-$ significance value, $n=10$

The density of the Russian desman burrows differs along the shoreline of the studied water bodies (Fig. 3). There were areas, where the burrows were located closely to each other, and areas, where the burrows were at a considerable distance one from another along the shoreline characterised by high Russian desman burrow density. The intervals between the burrows varied from less than $150 \mathrm{~m}$ and up to more than $200 \mathrm{~m}$ (Fig. 4). It is assumed that closely located burrows (distance less than $150 \mathrm{~m}$ ) belonged to one family. Sometimes the burrows are located on the opposite banks. The Russian desman made burrows in areas with a depth of more than $2 \mathrm{~m}$, typically when the lake depth was 3-4 m (Fig. 5).

\section{Discussion}

The typical water body inhabited by the Russian desman is rather deep and does not freeze down to the bottom. It has well-defined bottom sediments developed littoral, an open mirror of water, not marshy (at least at part of the water body) shores, and a rich invertebrate fauna. The presence of a shoreline covered by forest or shrubs is essential for the Russian desman hide-out during spring floods (Onufrenya \& Onufrenya, 2016). It is logical to assume that when choosing an optimal water body, the Russian desman takes into account three main parameters: shoreline comfortable for forming burrows, water temperature regime, and water body food capacity.

\section{Shoreline}

The shore and littoral slope gradient, as well as the vegetation protecting the shoreline from demolishing are keys to comfortable shoreline conditions. There was only one burrow (among 84 identified ones) on a shoreline, which was free of forest or shrub vegetation. $18 \%$ of the burrows were dug on the steppe shore, which, however, was densely overgrown with shrubs, and $81 \%$ of the burrows were dug on the shore, overgrown with forest. As usual, such a shore has a steep slope, since tree roots hold off the shoreline from caving during spring flood. 
Often, the Russian desman digs the burrow under the shrubs, because the passages are less showered under the roots. The forest vegetation is very important in floodplains (Onufrenya \& Onufrenya, 2016). The forest vegetation is the shield holding the spring waters in floodplain. There are sections with a quiet course in the forest areas, attractive for the Russian desman. When the flow slows down, the process of sedimentation of nutrients transported by hollow water is also enhanced. In water bodies, they improve the feeding conditions for the aquatic inverte- brates, which, in turn, serve as food for the Russian desman. In spring, during the flood period, the Russian desman finds reliable shelter in the hollows of trees and in large accumulations of influx delayed by the forest and is not demolished by the spring stream (Onufrenya et al., 2014). Both forest vegetation and separately growing aged trees are very important for the Russian desman. In open floodplain areas with high floods, they sometimes serve as the only refuges during the spring season (Onufrenya \& Onufrenya, 2016).
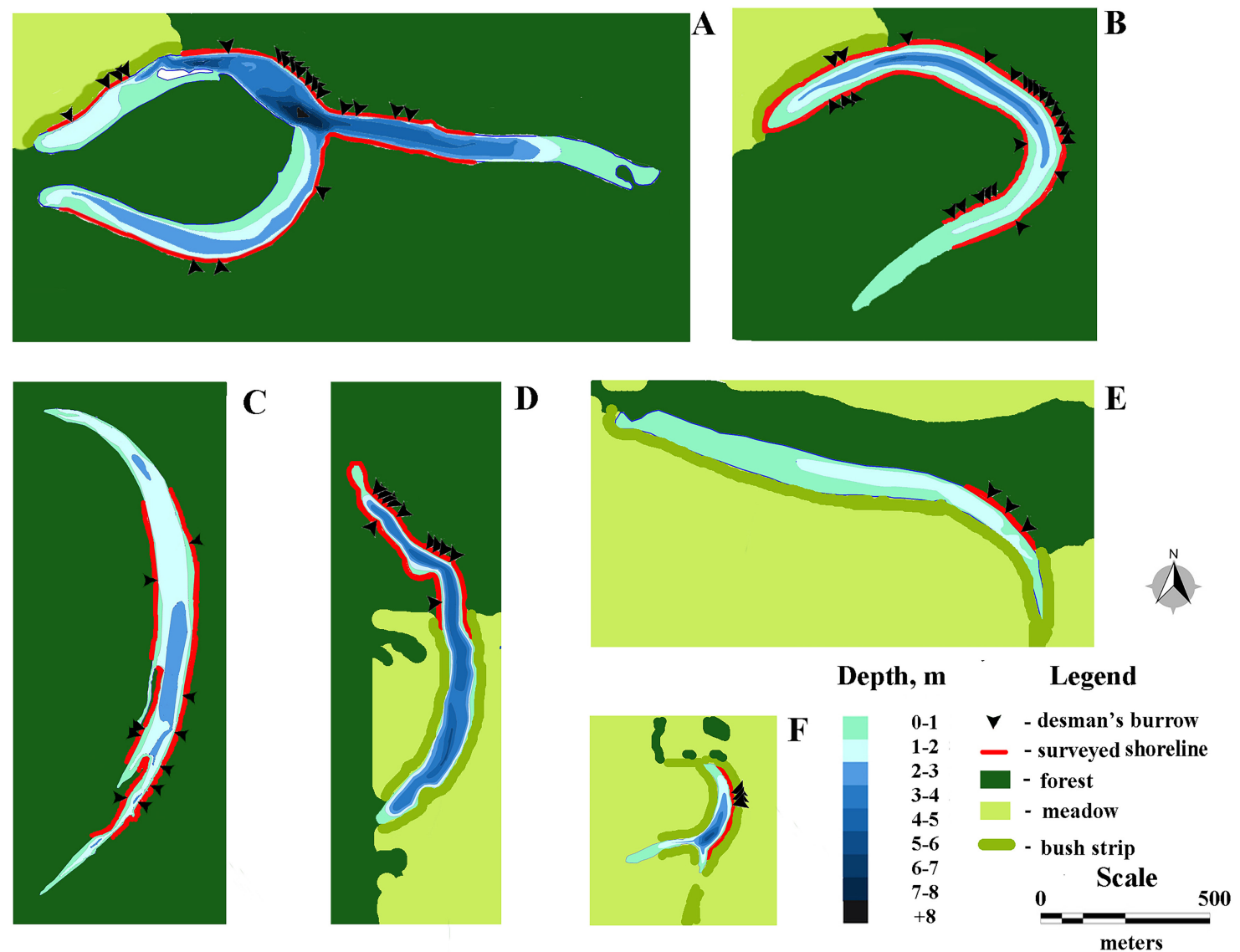

Fig. 3. The map of water bodies with high Russian desman burrow density (depth, shoreline vegetation and the burrows arrangement are indicated): A - lake Chaga; B - lake Kuryukaly; C - lake Lisa; D - lake Chebak; E - lake Staraya Staritsa; F - lake Krivoe.

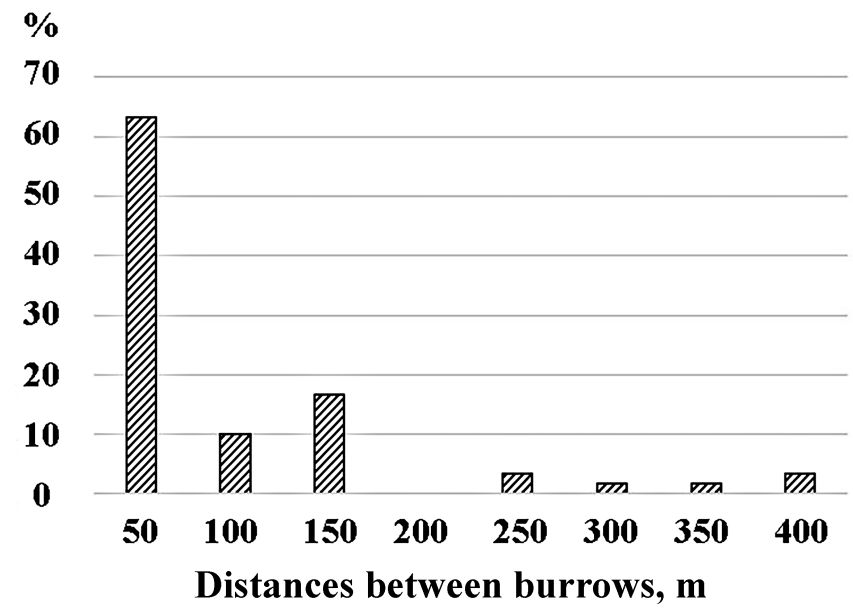

Fig. 4. The distance between the burrows located in the lakes with a high density (more than 5 burrows $/ \mathrm{km})(n=60)$.

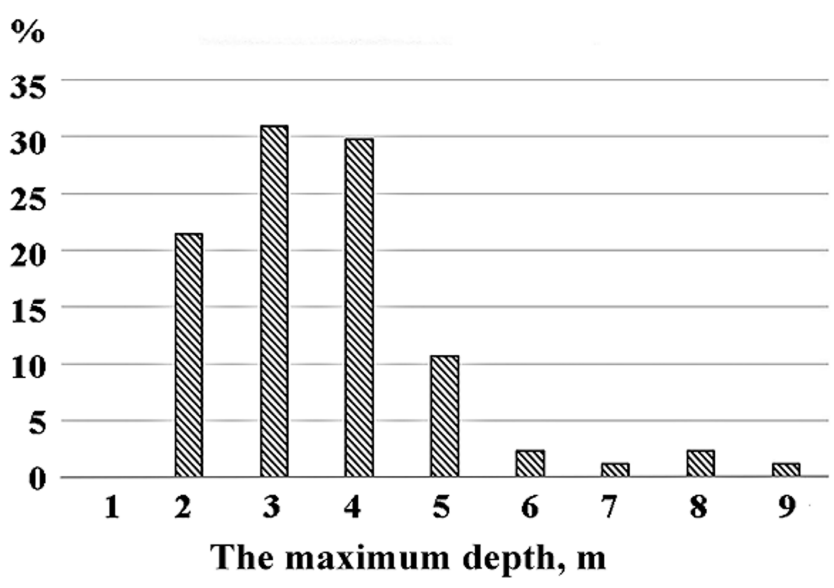

Fig. 5. The maximum water body depth along transect starting from the level of the Russian desman burrow $(n=84)$. 
The seasonal burrows have various structures: from the most primitive to multilevel ones with an extensive network of tunnels and several nests. The presence of forest and shrubs is very essential as the nesting chamber located among the roots is much more reliably protected from destruction (Onufrenya \& Onufrenya, 2016).

\section{Temperature conditions}

In the water body, the temperature conditions are the second parameter, important for several reasons. First of all, the well-warmed water bodies have a higher trophicity. However, in dry years without spring floods, the water bodies of the meadow floodplain become very shallow, and the water temperature rises significantly. Shallow lakes are unsuitable for wintering. Overheating of animals can be a limiting factor for their reproduction due to the inability to compensate for the heat production. The later is associated with reproductive processes due to a decrease in heat generation in somatic tissues. This is finally fraught with a reproductive system disorder (Rockett et al., 2001). Semi-aquatic life imposes severe restrictions on the Russian desman's thermoregulation system. So, mechanisms that reduce heat loss and prevent cooling in water can lead to fatal overheating of an organism on the land, and can create the problem of preserving heat in the winter and discharging its excess in the summer. The local and general heterothermia is the unique Russian desman's adaptation to this temperature regime. Two other adaptations of this animal are the presence of a bald tail («heat window») and the possibility to significantly decrease in the body temperature to the level $25-27^{\circ} \mathrm{C}$ without a noticeable change in animal activity, detected by remote infrared thermography (Minaev et al., 2016).

On the other hand, cold water at the bottom limits the growth rates of macrozoobenthos (Gusakov, 2010), which is the main food for the Russian desman. Therefore, the water bodies in a forest floodplain, deeper and colder, may be poorer on a food supply, which is the possible reason why the Russian desman prefers the water bodies located in the meadow floodplain (Onufrenya et al., 2012). However, due to the climate warming, deep and cold lakes are more favourable for the Russian desman's survival than the shoaled water bodies in the meadow floodplain (Eskova et al., 2018). The Russian desman's preference of the forested shorelines is possibly explained by this fact. However, in the colder year of 2016, the Russian desman's population density was higher in water bodies located in the meadow floodplain (Rutovskaya et al., 2018). Therefore, the existence of trends, but a lack of reliable statistical distinctions between Russian desman's preferences for biotopes, may depend on weather conditions of the current year.

\section{Fodder base}

The third factor seems to be the most important. Both Gastropoda and Bivalvia mollusks are the main food resource for the Russian desman (Borodin, 1963). They form an essential part of the bottom community in most of the water bodies in the River Sura floodplain (Podshivalina, 2018). Some water body parameters, such as the bottom slope degree and the dissolved oxygen concentration, affect the mollusk abundance. However, the prey abundance is not a factor for primary choosing the water body by the Russian desman, but the factor preconditioning a successful reproduction. In the River Sura floodplain, the food resources differ in qualitative structure optimum for the Russian desman. In $92 \%$ of the studied water bodies, the possible Russian desman prey is represented by the food objects that cover the food demand for this species the best and that make the main part of the benthos biomass (Podshivalina, 2018).

\section{Distribution of animals}

It is possible to identify separate families according to our data. Some of them are rather large (up to 12 individuals) living in the water bodies with a high Russian desman burrow density. In October, the scaling coefficient for calculation of burrows number is 1.1 (Borodin, 1963), since before the formation of ice, the animals actively dig reserve burrows. First of all, they are a reserve of air and a resting place where they can eat the prey found. The maximum accumulation included, e.g. 10-11 burrows, in the lakes Chaga and Kuryukaly (Fig. 4). A Russian desman family consists of a monogamous couple and their brood of the current year. The number of pups in a brood is $3-6$, on average 4 (Onufrenya \& Onufrenya, 2005). In addition, there are data that the females can bring two broods per year (Onufrenya \& Onufrenya, 2016). In autumn, the sex and age 
structure in joint family may vary, including the young animals of a different age. This testifies to the join of broods. Therefore, we can assume that a burrow complex belongs to one family with successful reproduction in the current year. Autumn burrow complexes are found close to the deepest sites of the water bodies (Fig. 4), because the freezing of these sites is the least probable and the bottom water temperature on sites deeper than $4 \mathrm{~m}$ is stable.

\section{Conclusions}

The fodder base is the main limiting factor for the Russian desman abundance in the particular water bodies. In turn, the biomass of the main food source for the Russian desman (mollusks) depends on a dissolved oxygen concentration, water body trophicity and the bottom slope, which are the indirect parameters of an optimum environment for the Russian desman. Other water body characteristics, such as depth and shoreline forest vegetation, may be factors defining temporary most suitable conditions depending on the summer features, namely, hot weather, etc. The combination of different conditions in a certain area allows the Russian desman to choose suitable water bodies, depending on climatic conditions of the year. There is a combination of steppe (meadow) and forest areas in the River Sura lower reaches floodplain. Thus, this floodplain is the best area for the Russian desman to inhabit. It is confirmed indirectly by the fact that in the XIX - early XX century, the Russian desman was usual in the River Sura lower reaches (Aspisov, 1955). Nowadays, the Russian desman population is restored there (Glushenkov et al., 2018) after a sharp decrease in the late XX - early XXI centuries (Khakhin, 2009).

\section{Acknowledgements}

The work is financially supported by the Russian Geographical Society (project № 29/2018-P) and the State Project of the A.N. Severtsov Institute of Ecology and Evolution of RAS «Ecological and evolutionary aspects of animals behaviour and communication. 01092018-0074». The authors are grateful to the staff of the Prisurskiy State Nature Reserve (E.V. Osmelkin, L.V. Egorov, A.Yu. Sevastyanov, A.A. Chetkin) for assistance in organising and providing the survey and to the «Club of Russian Desman Friends» (K.A. Eskova, I.A. Popov, M.A. Sergeyev, E.A. Vanisova, M.A. Berezhnoy, O.G. Ilchenko, F.A. Tumasyan, V.A. Suvatkin, D.S. Usova, M.A. Filippova, P.G. Targosh) for help in surveys of the Russian desman.

\section{References}

Abakumov V.A., Talskikh V.N., Popchenko V.I., Bulgakov G.P., Svirskaya N.L., Krineva S.V., Popchenko I.I., Semin V.A., Khromov V.M., Raspopov I.M., Margolina G.L., Voronova L.D., Pushkar I.N. 1992. Guide to hydrobiological monitoring of freshwater ecosystems. Saint-Petersburg: Gidrometeoizdat. 180 p. [In Russian]

Aleksandrov A.N. 2015. Toponymy of the oxbow lakes located in the buffer zone of the State Nature Reserve «Prisurskiy». Proceedings of the Prisurskiy State Nature Reserve 30(2): 140-145. [In Russian]

Aspisov D.I. 1955. The ways of Russian desman resources use due to Volga reservoir building. Uchenye Zapiski Kazanskogo Universiteta. Seriya Estestvennye Nauki 115(8): 217-223. [In Russian]

Barabash-Nikiforov I.I. 1968. Environmental factors affecting the Russian desmans and tasks of the desman's farm. In: Some problems of biology and soil science. Voronezh: Voronezh State University. P. 37-40. [In Russian]

Bogoslovsky B.B. 1960. Ozerovedeniye. Moscow: Moscow State University Publishing House. 335 p. [In Russian]

Borodin L.P. 1963. Russian desman. Saransk: Mordovia Book Publishing House. 301 p. [In Russian]

Carlson R.E. 1977. A trophic state index for lakes. Limnology and Oceanography 22(2): 361-369. DOI: 10.4319/ lo.1977.22.2.0361

Eskova K.A., Belovezhets K.I., Kosinsky A.A., Moreva Yu.O., Popov I.A., Rutovskaya M.V. 2018. Thermal mode of the habitats of the Russian desman (Desmana moschata, Talpidae, Soricomorpha). Povolzhskiy Journal of Ecology 1: 16-25. DOI: 10.18500/16847318-2018-1-16-25 [In Russian]

Glushenkov O.V., Aleksandrov A.N., Rutovskaya M.V. 2018. Russian desman habitat evaluation in the Sura River floodplain at the territory of the State Nature Reserve «Prisurskiy» buffer zone. Proceedings of the Prisurskiy State Nature Reserve 33: 105-114. [In Russian]

Gusakov V.A. 2010. Bottom meiofauna of karst lakes in the Vladimir region: composition and abundance level during spring - autumn period. In: Water invertebrate's ecology. Borok. P. 70-74. [In Russian]

Ivanov A.A. 1981. Characteristics of the forage base of the Russian desman in the middle course of the river Klyazma. In: Biological aspects of the protection of rare animals. Moscow: All-Russian Research Institute of Nature. P. 17-23. [In Russian]

Ivanov P.V. 1949. Classification of lakes of the world by size and by average depth. Bulletin of Leningrad State University 21: 29-36. [In Russian]

Khakhin G.V. 2009. Russian desman in danger: Dynamics of numbers and problem of protection. Moscow: Publishing House of the Biodiversity Conservation Centre. 104 p. [In Russian]

Khakhin G.V., Ivanov A.A. 1990. Desman. Moscow: Agropromizdat. 191 p. [In Russian] 
Kitaev S.P. 2007. Basic general limnology for hydrobiologists and ichthyologists. Petrozavodsk: Karelian Research Centre of RAS. 395 p. [In Russian]

Minaev A.N., Purikov A.V., Rutovskaya M.V., Makhotkina K.A., Surov A.V., Ivlev Yu.F. 2016. The radio transmitter for telemetric filing of shallow and average size animals body temperature. Zoologicheskii Zhurnal 95(1): 108-119. DOI: 10.7868/50044513416010104 [In Russian]

Mitropolsky V.I., Mordukhay-Boltovskoy F.D. 1975. Macrobenthos. In: Technique of internal water bodies biogeocenoses studying. Moscow: Nauka. P. 158170. [In Russian]

Nazyrova R.I. 2000. Ecological and geographical analysis of the distribution of Russian desman (Desmana moschata L., 1758) in connection with the problem of species protection. PhD Thesis. Moscow. 171 p. [In Russian]

Onufrenya A.S. 1986. Restoration of shallow floodplain water bodies as one of the methods to increase the number of Russian desmans. In: Natural resources of protected areas, the prospects for their protection in the conditions of accelerated scientific and technological progress. Voronezh. P. 114-115. [In Russian]

Onufrenya A.S., Onufrenya M.V. 2005. Some aspects of Russian desman Desmana moschata biology in the Oka river middle current. Proceedings of the Oka State Nature Biosphere Reserve 24: 92-134. [In Russian]

Onufrenya A.S., Onufrenya M.V. 2016. Russian desman in Oka basin. Proceedings of the Oka State Nature Biosphere Reserve 37: 1-204. [In Russian]

Onufrenya A.S., Onufrenya M.V., Rutovskaya M.V., Makhotkina K.A., Moreva Yu.O., Kabykhnova A.E., Sergeev M.A., Vozbranny A.E., Serdakova E.Yu., Mayorova S.O., Tenyakov S.A. 2012. Russian desman in the territory of the Vladimir region. In: Protected Areas in the Vladimir region and adjacent regions. Vladimir: Gamma-Print. P. 125-131. [In Russian]

Onufrenya M.V., Onufrenya A.S., Makhotkina K.A., Rutovskaya M.V. 2014. Russian desman survival srategy during spring flood. In: Behaviour and behavioural ecology of mammals. Moscow: KMK Scientific Press Ltd. P. 84. [In Russian]
Pesenko Yu.A. 1982. The principles and methods of the quantitative analysis in faunistic studies. Moscow: Nauka. 288 p. [In Russian]

Podshivalina V.N. 2018. Macrozoobenthos in floodplain lakes of the Sura River lower reaches as forage reserve for Desmana moschata Linnaeus, 1758. Proceedings of the Prisurskiy State Nature Reserve 33: 199-203. [In Russian]

Rockett J.C., Mapp F.L., Garges J.B., Luft J.C., Mori C., Dix D.J. 2001. Effects of hyperthermia on spermatogenesis, apoptosis, gene expression, and fertility in adult male mice. Biology of Reproduction 65(1): 229-239. DOI: 10.1095/biolreprod65.1.229

Rutovskaya M.V., Moreva Yu.O., Zaripova N.R., Kabykhnova A.E., Kosinsky A.A., Makhotkina K.A., Popov I.A., Sergeev M.A., Onufrenya A.S., Onufrenya M.V. 2013. Klyazma and its role in Russian desman preservation. In: Protected Areas in the Vladimir region and adjacent regions. Vladimir: Tranzit-IKS. P. 124-129. [In Russian]

Rutovskaya M.V., Onufrenya M.V., Onufrenya A.S. 2017. Russian desman (Desmana moschata: Talpidae) at the edge of disappearance. Nature Conservation Research 2(Suppl. 1): 100-112. DOI: 10.24189/ ncr.2017.020

Rutovskaya M.V., Glushenkov O.V., Bereznoy M.A., Eskova K.A., Popov I.A., Soboleva A.S. 2018. Current population status of the Russian desman on floodplain lakes of the Alatyrsky cluster buffer zone at the Nature Reserve «Prisurskiy». Proceedings of the Prisurskiy State Nature Reserve 33: 204-208. [In Russian]

Samarin V.F. 1975. The value of aquatic vegetation in the emanated lands of the European part of the USSR. Vestnik Zoologii 3: 25-28. [In Russian]

Sukhov V.P., Onufrenya A.S. 1990. Subcutaneous temperature of Russian desman in the autumn - winter period. In: System of thermoregulation when adapting the body to environmental factors. Novosibirsk. P. 104 105. [In Russian]

Wetzel R.G. 2001. Limnology: Lake and River Ecosystems. San Diego: Academic Press. 1006 p. 


\title{
УСЛОВИЯ ОБИТАНИЯ DESMANA MOSCHATA (TALPIDAE, EULIPOTYPHLA, МАММALIA) В ОХРАННОЙ ЗОНЕ ЗАПОВЕДНИКА «ПРИСУРСКИЙ» (РОССИЯ)
}

\author{
М. В. Рутовская ${ }^{1, *}$, А. Н. Александров ${ }^{2}$, В. Н. Подшивалина ${ }^{2,4}$, \\ А. С. Соболева ${ }^{1,3}$, О. В. Глушенков ${ }^{2,5}$ \\ ${ }^{1}$ Институт проблем экологии и эволюичи имени А.Н. Северияова РАН, Россия \\ ${ }^{2}$ Государственный природный заповедник «Присурский», Россия \\ ${ }^{3}$ Российский государственный аграрный университет - МСХА илени К.А.Тимирязева, Россия \\ ${ }^{4}$ Чувашский государственный университет имени И.Н. Ульянова, Россия \\ ${ }^{5}$ Национальный парк «Чаваш вармане», Россия \\ *e-mail:desmana@yandex.ru
}

В водоемах охранной зоны Присурского государственного природного заповедника (пойма низовья реки Суры) провели измерения батиметрии, численности макрозообентоса и плотности популяции русской выхухоли (Desmana moschata) в 21 водоеме. В шести озерах русская выхухоль отсутствовала. В девяти озерах плотность поселений составляла менее 5 жилых нор выхухоли на 1 км береговой линии. А еще в шести озерах плотность популяции выхухоли была высокой (более 5 нор на 1 км). Мы измеряли такие параметры водоемов как глубина, водородный показатель воды (pH) и концентрация растворенного кислорода, тип растительного покрова береговой линии (лес, кустарник, степь), антропогенная нагрузка и другие. Был проведен таксономический анализ макрозообентоса и взвешивание отдельных животных. Все измеренные параметры были соотнесены с плотностью поселения русской выхухоли и выявлены влияющие на нее факторы. В водоемах, в которых плотность поселения выхухоли более пяти нор на 1 км береговой линии, было обнаружено больше макрозообентоса, и особенно была высока биомасса моллюсков. В свою очередь, обилие моллюсков, являющихся основным кормом выхухоли, зависит от концентрации растворенного кислорода в воде, трофического состояния озера и уклона дна. Наибольшая плотность русской выхухоли отмечена в озерах с высокой биомассой брюхоногих моллюсков Lymnaea stagnalis и Viviparus (Contectiana) contecta. Было отмечено, что русская выхухоль предпочитает более широкие водоемы, берега которых плотно зарастают деревьями или кустарниками. Эти факторы могут выступать в качестве косвенных признаков водоема с оптимальными условиями обитания для русской выхухоли. Другие параметры водоема, такие как глубина, могут являться временным оптимумом. Сочетание водоемов с разными параметрами на одной территории позволяет русской выхухоли выбирать подходящие озера в зависимости от годовых климатических условий. В нижнем течении реки Суры сочетается степная (луговая) и лесная пойма, которая создает наиболее оптимальные условия для обитания русской выхухоли.

Ключевые слова: кормовая база, макрозообентос, Нижнее Присурье, пойма, русская выхухоль, условия обитания 